
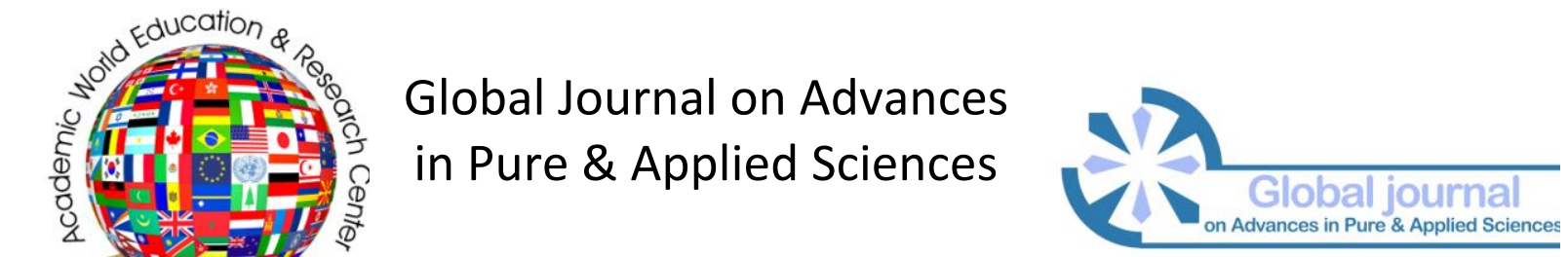

Issue 7 (2016) 183-189

Selected Paper of 2nd World Conference on Health Sciences (H-SCl 2015)

30 April-02 May 2015 Efes Surmeli Hotel \& Convention Center - İzmir, Kusadası, Turkey

\title{
Determination of descriptive characteristics of children with apendectomy surgery and related factors
}

\author{
Birsen Bilgen Sivri*, Health Services High School, Mevlana University, Konya, Turkey. \\ Serap Balcı, Florence Nightingale Nursing Faculty, Istanbul University, Istanbul, Turkey. \\ Zeynep Erkut, Florence Nightingale Nursing Faculty, Istanbul University, Istanbul, Turkey. \\ Ozlem Metreş, Okmeydanı Education and Training Hospital, Neonatal İntensive Care Unit, Istanbul, Turkey. \\ Burcu Aykanat Girgin, Health High School, Çankırı Karatekin University, Çankırı, Turkey.
}

\section{Suggested Citation:}

Sivri, B., B., BalcI, S., Erkut, Z., Metres, O., \& Girgin, A., B. (2016). Determination of descriptive characteristics of children with apendectomy surgery and related factors, Global Journal on Advances in Pure \& Applied Sciences. [Online]. 07, pp 183-189. Available from: http://www.world-educationcenter.org/index.php/paas

Received November 08, 2014; revised Deceember 03, 2014; accepted March 10, 2015.

Selection and peer review under responsibility of Prof. Dr. Fahrettin Sadikoglu, Near East University.

(C)2016 Academic World Education \& Research Center. All rights reserved.

\begin{abstract}
With morbidity and various symptoms; appendicitis is the most frequently seen health problem among the children and requires an emergent surgical intervention. Although it is estimated that appendicitis develops among $1 \%$ of the population under 15 years; it is stated that the most important factor that causes appendicitis is obstruction of lumen. The current study was cross-sectionally and descriptively undertaken in order to identify the descriptive characteristics of the children who had appendectomy surgery and the related factors. The population of the study was composed of the children aged 4-18 years who were hospitalized due to appendicitis at Bağcılar Training and Research Hospital Pediatric Surgery Service between 2012 and 2014. The sample of the population was consisted of a total of 64 children who accepted to participate in the study and stayed at the hospital during research period. The data were gathered using a questionnaire form designed by the researchers.37.5\% of the participant children were girls and $62.5 \%$ of the participant children were boys; mean age was $11.48 \pm 3.48$ years. Most of the mothers (60.9\%) and fathers $(60.9 \%)$ had primary school degree. $43.8 \%$ of the families had appendectomy previously, $95.3 \%$ did not have any chronic diseases. $25 \%$ of the children had a perforated appendix and most of them presented such symptoms as pain (70.3\%), nausea
\end{abstract}

* ADDRESS FOR CORRESPONDENCE: Birsen Bilgen Sivri, Mevlana University Health Services High School, Konya 42003, Turkey. E-mail address: bbsivri@mevlana.edu.tr , oneyou2009@gmail.com / Tel.: +90-444-42 43-1397 
Sivri, B., B., BalcI, S., Erkut, Z., Metres, O., \& Girgin, A., B. (2016). Determination of descriptive characteristics of children with apendectomy surgery and related factors, Global Journal on Advances in Pure \& Applied Sciences. [Online]. 07, pp 183-189. Available from: $\underline{\text { www.propaas.eu }}$

(70.3\%), lack of appetite (78.1\%), vomiting(67.2\%), fever (39.1\%). 38\% of the mothers performed a practice (hotcompress, cold-compress, giving massages to abdomen, giving pain killers, hot teas of mint leaves and lemon, wrapping the abdomen, etc.) before the children were taken to hospitals. Additionally; it was found out that the children swallowed seeds of the fruits (29.3\%), did not peel the fruits (61.5\%), swallowed chewing gums (35.4\%) and ate legumes and ate bones without chewing (16.9\%).

Keywords: Appendicitis, appendectomy, child

\section{Introduction}

Acute appendicitis is a condition that is most commonly seen in pediatric age group and requires an emergent intervention. Appendectomy is the most commonly performed abdomen operation among this age group [7]. It is estimated that appendicitis develops in $1 \%$ of the population aged below 15 years $[6,10]$.

The most important factor in the etiology of appendicitis is the obstruction of appendix lumen. When the reasons of this obstruction is examined; fecalith, lymphoid tissue hyperplasia, tumors, foreign bodies (particularly fruit seeds), parasites -mainly ascaris- play important roles in the obstruction of appendix although its incidence varies according to the age groups. Lymphoid tissue hyperplasia is the most common cause of obstruction of appendix lumen among the children; fecalith among the adult population and tumors among the elderly population $[10,13]$. According to incidence rate; some of the foreign bodies that cause appendicitis are metal needles, buckshots swallowed with hunted animals, bones, seeds, stones, shells of the dried fruits, coins, nails, teeth, keys, egg shell, toothpicks, chewing gums, hair, thermometer pieces, dental fillings, bristles of tooth brushes, plastic items and seeds of watermelon $[6,9,10,13]$. Acute appendicitis in children is characterized with abdomen pain, nausea and vomiting, sensitivity in lower right hand side of the abdomen after physical examination and leukocytosis findings in rebound, defense and complete blood count [8]. In order to diagnose appendicitis; it is important to get anamnesis, physical examination, laboratory and radiological analyses as well as observation of the patient [5]. A late diagnosis may lead to such complications as perforation, abscess formation, sepsis and bowel obstruction [12].

The number of the studies on descriptive characteristics of the children who have had appendectomy due to appendicitis diagnosis and the factors that caused appendicitis is limited [5, 12, 14]. The current study aimed at identifying the descriptive characteristics of the children who had surgical operation due to appendicitis diagnosis and the related factors that caused appendicitis.

\section{Materials and Methods}

The current study was descriptively planned to explore the descriptive characteristics of the children who had appendectomy and the related factors that caused appendicitis. The population of the study was composed of the children aged 4-18 years who were hospitalized due to appendicitis at Bağcılar Training and Research Hospital Pediatric Surgery Service between 2012 and 2014. The sample of the population was consisted of a total of 64 children who accepted to participate in the study and stayed at the hospital during research period. Before data collection phase initiated; necessary official permissions, ethical committee permissions and written informed consents from the parents were obtained. The data were gathered using a questionnaire form designed by the researchers in line with the relevant literature and face-to-face interviews. The questionnaire form included 30 questions addressing socio-demographic characteristics, disease history and the appendicitis causing factors. 
Sivri, B., B., Balcı, S., Erkut, Z., Metres, O., \& Girgin, A., B. (2016). Determination of descriptive characteristics of children with apendectomy surgery and related factors, Global Journal on Advances in Pure \& Applied Sciences. [Online]. 07, pp 183-189. Available from: www.propaas.eu

\section{Results}

$37.5 \%$ of the participant children were girls and $62.5 \%$ of the participant children were boys; mean age was $11.48 \pm 3.48$ years. The age of the most children $(46.9 \%)$ in the families was between 3 and 4 years. Most of the mothers (60.9\%) and fathers (60.9\%) had primary school degree and $82.8 \%$ of the mothers were not employed. According to the statements of the parents; $73.4 \%$ of them had moderate income. $43.8 \%$ of the families had appendectomy previously while $56.3 \%$ did not have any family members who had appendectomy.

Table 1. Demographic characteristics about the children and the parents $(N=64)$

\begin{tabular}{|c|c|c|}
\hline Characteristics & $\mathrm{n}$ & $\%$ \\
\hline \multicolumn{3}{|l|}{ Gender } \\
\hline Girls & 24 & 37.5 \\
\hline Boys & 40 & 62.5 \\
\hline \multicolumn{3}{|l|}{ Number of the children in the family } \\
\hline $1-2$ & 26 & 40.6 \\
\hline $3-4$ & 30 & 46.9 \\
\hline 5 and above & 8 & 12.5 \\
\hline \multicolumn{3}{|l|}{ Educational status of the mothers } \\
\hline Literate & 15 & 23.5 \\
\hline Primary school & 39 & 60.9 \\
\hline High school & 6 & 9.4 \\
\hline University & 4 & 6.3 \\
\hline \multicolumn{3}{|l|}{ Educational status of the fathers } \\
\hline Literate & 5 & 7.8 \\
\hline Primary school & 40 & 62.5 \\
\hline High school & 14 & 21.9 \\
\hline University & 5 & 7.8 \\
\hline \multicolumn{3}{|l|}{ Employment status of mothers } \\
\hline Employed & 11 & 17.2 \\
\hline Unemployed & 53 & 82.8 \\
\hline \multicolumn{3}{|c|}{$\begin{array}{l}\text { Income Status (According to the statement of the } \\
\text { families) }\end{array}$} \\
\hline Unsatisfactory & 7 & 10.9 \\
\hline Moderate & 47 & 73.4 \\
\hline Satisfactory & 10 & 15.6 \\
\hline \multicolumn{3}{|c|}{ The family members with appendicitis operation } \\
\hline \multirow[t]{2}{*}{ No } & 28 & 43.8 \\
\hline & 36 & 56.3 \\
\hline \multirow[t]{2}{*}{ Mean age of the children (years) } & \multicolumn{2}{|c|}{ mean \pm SD } \\
\hline & & .48 \\
\hline
\end{tabular}


Sivri, B., B., Balcı, S., Erkut, Z., Metres, O., \& Girgin, A., B. (2016). Determination of descriptive characteristics of children with apendectomy surgery and related factors, Global Journal on Advances in Pure \& Applied Sciences. [Online]. 07, pp 183-189. Available from: www.propaas.eu

Tables 2. Distribution of the risk factors that might cause appendicitis development $(\mathrm{N}=64)$

\begin{tabular}{lcc}
\hline Characteristics & $\mathrm{n}$ & $\%$ \\
\hline Presence of an infection within the last one week & 13 & 20.3 \\
Yes & 51 & 79.7 \\
No & 1 & 1.6 \\
Swallowing foreign body before signs initiated & 63 & 98.4 \\
Yes & & \\
No & 19 & 29.7 \\
Swallowing the seeds of the fruits & 45 & 70.3 \\
Yes & & \\
No & 11 & 17.2 \\
Swallowing the foods without chewing & 53 & 82.8 \\
Yes & & \\
No & 8 & 12.5 \\
Eating shells of the dried fruits & 56 & 87.5 \\
Yes & & \\
No & 40 & 62.5 \\
Peeling the fruits & 24 & 37.5 \\
Yes & & \\
No & 23 & 36.0 \\
Swallowing chewing gums & 41 & 64.0 \\
Yes &
\end{tabular}

When the distribution of the risk factors that might cause appendicitis development was examined; $20.3 \%$ of the children had infection in the last one week and $1.6 \%$ of the children swallowed a foreign body before the signs initiated. It was found out that $29.7 \%$ of the children swallowed seeds of the fruits, $17.2 \%$ of them swallowed the foods without chewing, $12.5 \%$ of them ate shells of the dried fruits, $37.5 \%$ of them did not peel the fruits and $36 \%$ of them swallowed chewing gums. It was detected that $17.2 \%$ of the children had parasites in bowels previously whereas $82.8 \%$ of them did not.

Table 3. Complaints of the children before hospitalization $(\mathrm{N}=64)$

\begin{tabular}{lrc}
\hline Complaints & $\mathrm{n}$ & $\%$ \\
\hline Fever & 25 & 39.0 \\
Nausea & 45 & 70.3 \\
Vomiting & 43 & 67.2 \\
Lack of appetite & 50 & 78.1 \\
Constipation & 20 & 31.2 \\
Diarrhea & 23 & 35.9 \\
Pain (mainly in lower right hand side of the abdomen and entire abdomen) & 45 & 70.3 \\
Perforation & 16 & 25.0 \\
\hline
\end{tabular}

When the complaints of the participant children before they were hospitalized were investigated, it was seen that fever was $39 \%$, nausea was $70.3 \%$, vomiting was $67.2 \%$, lack of appetite was $78.1 \%$, constipation was $31.2 \%$, diarrhea was $35.9 \%$ and pain was $70.3 \%$. The identified pain was mostly in lower right hand side of the abdomen and the appendix of the $25 \%$ of the children was perforated. 
Sivri, B., B., Balcı, S., Erkut, Z., Metres, O., \& Girgin, A., B. (2016). Determination of descriptive characteristics of children with apendectomy surgery and related factors, Global Journal on Advances in Pure \& Applied Sciences. [Online]. 07, pp 183-189. Available from: www.propaas.eu

Table 4. Practices of the parents before they went to the hospital $(\mathrm{N}=64)$

\begin{tabular}{|c|c|c|}
\hline Practices Done At Home & $\mathrm{n}$ & $\%$ \\
\hline \multicolumn{3}{|l|}{ Did you perform any practices before going to hospital } \\
\hline Yes & 24 & 37.5 \\
\hline No & 40 & 62.5 \\
\hline \multicolumn{3}{|l|}{ Practices performed $(n=24)$} \\
\hline Hot compress (on abdomen or feet)) & 9 & 37.5 \\
\hline Giving analgesics & 9 & 37.5 \\
\hline Giving antibiotics & 1 & 4.2 \\
\hline $\begin{array}{l}\text { Other (massage. hot teas of mint leaves and lemon, } \\
\text { antiflatulent drugs, cold-compress) }\end{array}$ & 5 & 20.8 \\
\hline
\end{tabular}

The parents performed some practices to $37.5 \%$ of the children while they did not perform any practices to $62.5 \%$ of the children. The practices mostly performed were hot-compress (37.5\%), giving analgesics (37.5\%), giving antibiotics (4.2\%) and other practices (massaging, hot teas of mint leaves and lemon, antiflatulent drugs, cold-compress) (20.8\%).

Table 5. Comparison of time spent before going to hospital, practices of the parents before hospitalization and perforation development $(\mathrm{N}=64)$

\begin{tabular}{|c|c|c|c|c|c|c|}
\hline \multirow{3}{*}{ Characteristics } & & \multicolumn{4}{|c|}{ Perforation Development } & \multirow{3}{*}{$X_{p}^{2}$} \\
\hline & & \multicolumn{2}{|l|}{ Yes } & \multicolumn{2}{|l|}{ No } & \\
\hline & & Number & Percentage & Number & Percentage & \\
\hline \multirow{4}{*}{$\begin{array}{l}\text { Time spent before } \\
\text { going to hospital }\end{array}$} & The same day & 7 & 43.8 & 26 & 54.2 & \multirow{4}{*}{$\begin{array}{l}1.59 \\
0.45\end{array}$} \\
\hline & (0-24 hours) & & & & & \\
\hline & $\begin{array}{l}\text { The following } \\
\text { day (25-48) } \\
\text { hours }\end{array}$ & 7 & 43.8 & 13 & 27.1 & \\
\hline & 3 days and later & 2 & 12.5 & 9 & 18.8 & \\
\hline \multirow{3}{*}{$\begin{array}{l}\text { Any practice } \\
\text { performed by the } \\
\text { parents before } \\
\text { going to hospital }\end{array}$} & Yes & 8 & 50.0 & 8 & 50.0 & \multirow{3}{*}{$\begin{array}{l}2.85 \\
0.09\end{array}$} \\
\hline & & & & & & \\
\hline & No & 13 & 27.1 & 35 & 72.9 & \\
\hline
\end{tabular}

When time spent before going to hospital and perforation development were compared; it was seen that there was not a statistically significant difference between $(p>0.05)$. When the practices of the parents before hospitalization and perforation development were compared; it was noted that there was not a statistically significant difference between ( $p>0.05$ ) (Table 5).

\section{Discussion}

Although appendicitis is the most commonly seen problem after inguinal region diseases in pediatric surgery [11] and general surgery clinics; it ranks first among the causes of surgery among the children who go to hospital with acute abdominal pain $[3,4]$.

The most important risk factor of acute appendicitis is lumen obstruction. One of the most commonly seen reasons of obstruction is fecalith. Other less frequently encountered risk factors are 
Sivri, B., B., BalcI, S., Erkut, Z., Metres, O., \& Girgin, A., B. (2016). Determination of descriptive characteristics of children with apendectomy surgery and related factors, Global Journal on Advances in Pure \& Applied Sciences. [Online]. 07, pp 183-189. Available from: $\underline{\text { www.propaas.eu }}$

lymphoid tissue hyperplasia, obstruction of appendix lumen with barium after barium examinations, fruit and vegetable seeds and bowel worms -mainly ascaris-[15]. Although appendicitis cases caused by foreign body are rarely seen; most of the foreign bodies taken orally pass through digestion system without any problem. Likewise; it was reported in $\% 0.005$ of the appendectomy samples that there was appendicular foreign bodies [9]. It was identified that more than $60 \%$ of the answers given by the participant children was no when the children were asked whether or not they demonstrated such behaviors as swallowing seeds of the fruits, swallowing foods without chewing, eating shells of the dried fruits and swallowing chewing gums. This result was similar to the one reported in literature that seeds of fruits and vegetables were the less frequently encountered causes of obstruction.

Clinical signs and symptoms of acute appendicitis are generally periumbilical pain (visceral, unlocalized), lack of appetite, nausea and/or vomiting, sensitivity and pain in lower right hand side of the abdomen, fever and leukocytosis $[2,4]$. When the complaints of the children before they were hospitalized were examined; they had lack of appetite (78.1\%), pain in lower right hand side of the abdomen (70.3\%), nausea (70.3\%), vomiting (67.2\%) and fever (39\%). Although the most frequently reported sign and symptom in literature was abdomen pain; symptoms accompanying abdomen pain are often manifest among the children. The study of Bicer indicated that vomiting ranked first among the accompanying symptoms but in the current study it was noted that lack of appetite was more manifest than pain [5].

It is very crucial for the patients with appendicitis to go to hospital within 24 hours. Complications occur and the diagnosis gets difficult because patients go to hospital late, use home-remedies and analgesics and perform other practices at home themselves [15]. In the study; it was seen that the parents performed some practices to $37.5 \%$ of the children before they went to hospital and most of these practices were hot-compress (37.5\%) and giving analgesics (37.5\%) (Table4). It was detected that $43.8 \%$ of the parents went to the hospital within 24 hours when the first signs and symptoms initiated and no statistically significant difference existed between the time spent before going to hospital and perforation development ( $>>0.05$ ) (Table 5). In the study done Akova et al., too, it was identified that most of the families (55\%) went to the hospital within 24 hours when the first signs and symptoms initiated. It is a positive act that families go to hospital within 24 hours [1]. However; applying hot-compress and giving analgesics are risky behaviors. Because different methods like these repress abdominal pain; they may cause time-loss and thus perforation. Therefore; families should be informed about these issues.

\section{Conclusion and Recommendation}

It was seen that the children with appendectomy were mainly boys, the mean age of the subjects was $11.48 \pm 3.48$ years, $25 \%$ of them developed perforation, mothers performed some practices to the $37.5 \%$ of the children at home before they were hospitalized (hot compress, cold compress, massage, giving pain killers, mint-lemon tea, wrapping the abdomen). In addition; it was found out that children swallowed seeds of the fruits $(29.3 \%)$, did not peel the fruits $(61.5 \%)$, swallowed chewing gums (354\%) and swallowed legumes and ate bones without chewing (16.9\%). It is recommended that families be informed of the signs and correct interventions about appendicitis and studies with larger samples and control groups be undertaken in order to determine the related risk factors of appendicitis.

\section{References}

[1] Akova, S., Yakut, K., Yakut, N., Guven, S., Yazar, A. S., Aydoğdu, S., \& Kaymakci, A. (2013). Evaluation of patients with acute abdominal pain admitted to the pediatric emergency department. Gaziantep Medical Journal, 19(2), 60-64. 
Sivri, B., B., Balcı, S., Erkut, Z., Metres, O., \& Girgin, A., B. (2016). Determination of descriptive characteristics of children with apendectomy surgery and related factors, Global Journal on Advances in Pure \& Applied Sciences. [Online]. 07, pp 183-189. Available from: www.propaas.eu

[2]Albayrak, T, Kasim, I., Kahveci, R., Sencan, I., Unsal S., \& Akca, O. (2012). An acute appendicitis case; Ankara Medical Journal, 12(3), 153-155.

[3]Aren, A., Gokce, A., H., Gokce, F., S., Ozakay, K., Aksoy, S., Karagoz, B., Celik, G., \& Aydin, I. (2009). The correlation of acute appendicitis with age, gender, leukocyte values, Istanbul Med J, 10(3), 126-129.

[4]Arıca V., Arıca S., Tutanc, M., \& Gucuk, S. (2012). Evaluation of the children who went to emergency room with acute abdomen pain in Van Province, 14(1), 14-18.

[5]Bicer, S. (2009). Analyses of the children with acute abdomen pain and other acute abdomen symptoms at pediatric emergency room. Bakirkoy Mediciene Journal, 5, 96-102.

[6]Ekingen, G., Guvenc, B., H., Senel, U., \& Korkmaz, M. (2003). Fluoroscopy guided laparoscopy in the management of intra abdominal foreign body. J Pediatr Surg, 38, E19-20.

[7]Erbay, G., Karadeli, E., \& Koc, Z. (2012). Evaluation of ultrasonography and laboratory findings in diagnosing childhood appendicitis. Cukurova University, Medicine Faculty Journal, 37(2), 84-89.

[8]Kaiser, S., Frenckner, B., \& Jorulf, H., K. (2004). Suspected appendicitis in children: US and CT a prospective randomized study. Radiology, 231, 427-433.

[9] Koseogulları, A., A., Ozel, S., K., Bakal, U., \& Kazez, A. (2006). A rare cause of appendicitis: seeds of fruit. Firat Medicine Journal, 11(1), 73-74.

[10]Miller, G., G., Fraser, G., C., \& Vancouver, G., S. (1996) Plonidal appendicitis' or 'the hair of the dog: an unusual case of foreign body perforation of the appendix. J Pediatr Surg, 31, 703.

[11]Narci, A., Tuncer, A., A., \& Cetin Kursun S. (2009). Diagnosis value of neutrophil lymphocyte ratio in childhood appendicitis, Kocatepe Medicine Journal, 10(1-2-3), 5-7.

[12]Sivit, C., J., Siegel, M., J., Applegate, K., E., \& Newman, K., D. (2001). When appendicitis is suspected in children. Radiographics, 21(1), 247-262.

[13]Sukhotnik, I., Klin, B., \& Siplovich, L. (1995). Foreign-body appendicitis. J Pediatr Surg, 30, 1515-1516.

[14]Sulu, B., Gunerhan, Y., Palanci, Y., Isler B., \& Caglayan, K. (2010). Epidemiological and demographic features of appendicitis and influences of several environmental factors. Ulus Trauma Emergent Surgery Journal, $36(1), 38-42$.

[15]Yavuz S. (2009). A retrospective assessment of alvarado score and ultrasonography results among the operated acute appendicitis patients. Dissertation for specialty in medicine. Republic of Turkiye, Ministry of Health, İstanbul Goztepe Training and Research Hospital, Coordinatorship of Family Medicine Department. İstanbul. 